\title{
EU Military Operations as a Tool in the EU's Foreign Policy Toolbox - The Main Trends and Limitations
}

\begin{abstract}
The main aim of the article is to characterise and analyse EU military operations, taking into account their objectives, assumptions, successes as well as their limitations and weaknesses. The author focusses his research on EU activities in Sub-Saharan Africa.

The following research questions were posed:

- what is the specificity and characteristic features of EU military crisis management operations;

- to what extent and in what direction are military operations launched by the EU evolving;

- in what way do EU military operations influence the perception of the EU as a civilian and normative power and affect the development of the EU as a security actor;

- what are the main limitations and weaknesses of EU military operations and what is their future in EU foreign policy?

The author applied the following research methods: factorial, comparative, scenario, quantitative, and qualitative analysis.

The main conclusion is that the EU's military operations and its military training missions should solely be perceived as one of the elements (measures) in EU foreign policy. As has been indicated in the title of the article, they are "a tool in the EU's foreign policy toolbox".
\end{abstract}

Keywords: Common Security and Defence Policy, European Union, Military Operations, European Union Training Missions, Military Missions, Foreign Policy, Crisis Management

^ Kamil Zajączkowski - University of Warsaw, e-mail: k.zajaczkowski@uw.edu.pl, ORCID: 0000-0002-7412-858X. 


\section{Introduction - Methodological Aspects}

European Union military operations, in addition to civilian missions, have been conducted since 2003 under the European Security and Defence Policy, and subsequently the Common Security and Defence Policy. The operations encompass activities related to crisis management, defined by the EU as Petersberg tasks. The research aim of this article is to present the essence and significance of EU military operations in its foreign policy, and more broadly as one of the instruments the EU has at its disposal in the array of resources in the EU's international activity, as well as to characterise the scale and scope of these operations, and demonstrate the premises determining the decisions to launch them. The foregoing allows one to focus on the article's main research objective, which is to understand the phenomenon of the EU military crisis management operations and to try to illustrate their evolution over the course of almost twenty years, especially in terms of the scope and type of activities, the number of soldiers and the duration of these operations, as well as the extent of the integration of military operations with other EU activities.

The EU-run military operations are analysed on the example of SubSaharan Africa. The choice of this region as a case study of EU-implemented military operations is well-grounded and intentional. This region is something of a laboratory for the international activities of the European Union. It was in Sub-Saharan Africa that the first EU military operation outside of Europe (and the second in general) under the CSDP took place, and it is there, where the vast majority (10 out of 14) of EU military operations/missions are sent.

As a result of selecting this research problem and objective, the following research questions need to be answered:

- what is the specificity and characteristic features of the EU military crisis management operations;

- to what extent and in what direction are the military operations launched by the EU evolving;

- in what way do the EU military operations influence the perception of the EU as a civilian and normative power and affect the development of the EU as a security actor;

- what are the main weaknesses of EU military operations and what is their future in EU foreign policy?

Taking into account the foregoing questions, I have formulated the following hypotheses. Hypothesis No. 1: The European Union is not and will never be a typical military power. The mere fact that the EU is conducting military crisis management operations is not tantamount to the 
EU having such plans or intentions. These operations should only be perceived as one of the instruments in the array of measures the EU has at its disposal in its international activity and should be assessed through that prism. Hypothesis No. 2: In recent years, one should observe an evolution as regards the scope of military operations. They are of training rather than combat in nature, are much smaller in terms of numbers, and are motivated by EU security concerns (such as terrorism or migration).

When writing this article, the following research methods were applied. I used the factor method to indicate the premises determining the shape and specificity of EU military operations. The systemic method, however, allowed me to examine the elements of the system, i.e., the EU's external relations, their interrelation, and the consequences resulting therefrom for the functioning and evolution of the system, and thus for the EU's military operations. The comparative method was applied so as to analyse individual EU military operations in Sub-Saharan Africa. Quantitative and qualitative analysis enabled me to compare and evaluate the effectiveness of EU military operations. However, when trying to outline the direction in which military crisis management operations would develop, the scenario method was used.

In this article, I applied the interdisciplinary approach by using the achievements of various theories of international relations, which allowed me to present the essence of the EU military operations from various theoretical perspectives, as well as to highlight those that best reflect the reality in that respect. Therefore, where there is reference to a realistic perspective in the analysis, I perceived EU military operations as a derivative of the interests of individual states. Due to the specificity of the EU's policy in the international arena, it is impossible to adequately analyse the foreign policy of the European Union without referring to the liberal idea. The promotion of political and economic values of liberalism underpins the EU's international activity, including military operations. Liberalism is, at the same time, set in the group of rationalist theories since it assumes that governments are primarily guided by the logic of "consistency". Hence, decisions taken by governments as regards the participation of their soldiers in EU military operations is the result of cost-benefit calculations and the pursuit of maximising their interests. Liberalism also has an exceptional potential to explain the concept of civilian power and to place EU military operations in its framework. Constructivism, however, has been applied to explain the relationship between the normative activity of the EU, as one of the key EU strategies in the international sphere, and the military activities of the EU. 


\section{The Scale and Scope of EU Military Operations}

The European Union has conducted (some are still ongoing) a total of 37 civilian and military crisis management missions and operations (as of $1^{\text {st }}$ November 2021) in 22 countries on three continents, including 23 civilian and 14 military operations. Half of them (10 military and 9 civilian) have been executed (implemented) in Sub-Saharan Africa. ${ }^{1} 11$ civilian missions and 7 military operations of the EU (including four civilian and 5 military respectively in Sub-Saharan Africa) are currently ongoing.

The largest number of military operations and missions, a total of 10 out of 14, the EU has conducted or is still running in Sub-Saharan Africa, including such regions as the Sahel, the Horn of Africa, and West Africa. What distinguishes Sub-Saharan Africa as regards EU missions and operations is the fact that the number of launched military operations is comparable to that of civilian missions. In the rest of the world, EU civilian missions prevail.

Africa, especially its Sub-Saharan part, will remain an area of special penetration by the EU as regards military operations (as well as civilian missions). The foregoing is due to a number of reasons. The EU's geographical proximity and its concerns as regards the dissemination of negative phenomena, which may pose a threat to EU countries, i.e., terrorism or organised crime, an influx of migrants (especially illegal ones) - the latter being exacerbated by the ever-increasing migration pressure on the African continent (it is estimated that in 2050 the continent will be inhabited by over 2 billion people). The stability of the African continent will also be adversely affected by the processes related to climate change and its consequences being of a social and economic (droughts and floods will intensify poverty and indigence, especially in agricultural regions) as well as political (e.g., conflicts over water resources) nature, but also challenges related to the pandemic (and post-pandemic) times. Although Covid has affected Africa in a far less severe way than other continents, Europe and Latin America in particular, the long-term effects of the pandemic, as the United Nations forebodingly predicts, will be substantial for the African continent. ${ }^{2}$ Therefore, irrespective of certain positive changes that have been undergoing in Africa since the beginning of the 21st century (e.g., constant and steady economic growth in majority of the countries; a grow-

1 See more: https://eeas.europa.eu/topics/military-and-civilian-missions-andoperations/430/military-and-civilian-missions-and-operations_en (access 28.11.2021).

${ }^{2}$ United Nations. Economic Commission for Africa, Policy brief: impact of COVID-19 in Africa, Addis Ababa, 20 May 2020; Covid-19 in Africa. At the end of the line, "The Economist”, 06-12 February 2021, pp. 23-25. 
K. Zajączkowski, EU Military Operations as Tool in the EU's Foreign Policy...

Table 1. Overview of EU military operations

\begin{tabular}{|c|c|c|}
\hline $\begin{array}{l}\text { Operation } \\
\text { (Country) }\end{array}$ & $\begin{array}{l}\text { Military person- } \\
\text { nel (peak number } \\
\text { of personnel) }\end{array}$ & Period \\
\hline Concordia (fYROM) & 400 & $\begin{array}{l}\text { 31 March } 2003-15 \text { December } \\
2003\end{array}$ \\
\hline Artemis (DR Congo) & 1807 & $\begin{array}{l}\text { 12 June } 2003 \text { - } 1 \text { September } \\
2003\end{array}$ \\
\hline $\begin{array}{l}\text { EUFOR Althea (Bosnia } \\
\text { and Herzegovina) }\end{array}$ & 7000 & 2 December 2004 - present \\
\hline $\begin{array}{l}\text { EUFOR RD Congo (DR } \\
\text { Congo) }\end{array}$ & 2259 & $\begin{array}{l}\text { 30th July } 2006-30 \text { November } \\
2006\end{array}$ \\
\hline $\begin{array}{l}\text { EUFOR Tchad/RCA } \\
\text { (Chad - Central African } \\
\text { Republic }\end{array}$ & 3700 & $\begin{array}{l}28 \text { January } 2008-15 \text { March } \\
2009\end{array}$ \\
\hline $\begin{array}{l}\text { EU NAVFOR Atalanta } \\
\text { (coast of Somalia) }\end{array}$ & 1943 & 8 December 2008 - present \\
\hline $\begin{array}{l}\text { EUTM Somalia (Ugan- } \\
\text { da and Somalia) }\end{array}$ & 128 & 7 April 2010 - present \\
\hline EUTM Mali (Mali) & 640 & 18 February 2013 - present \\
\hline $\begin{array}{l}\text { EUFOR RCA (Central } \\
\text { African Republic) }\end{array}$ & 700 & $\begin{array}{l}\text { 10 February } 2014-15 \text { March } \\
2015\end{array}$ \\
\hline $\begin{array}{l}\text { EUMAM RCA (Central } \\
\text { African Republic) }\end{array}$ & 70 & 16 March 2015 - 16 July 2016 \\
\hline $\begin{array}{l}\text { EUTM RCA (Central } \\
\text { African Republic) }\end{array}$ & 170 & 16 July 2016 - present \\
\hline $\begin{array}{l}\text { EUNAVFOR Med } \\
\text { Sophia (Mediterranean } \\
\text { Sea) }\end{array}$ & 1666 & 22 June 2015 - 31 March 2020 \\
\hline $\begin{array}{l}\text { EUNAVFOR } \\
\text { Med IRINI }\end{array}$ & - & 31 March 2020 - present \\
\hline EUTM Mozambique & 140 & 15 October 2021 - present \\
\hline
\end{tabular}

Source: https://eeas.europa.eu/topics/military-and-civilian-missions-and-operations/ 430/military-and-civilian-missions-and-operations_en (access 28.11.2021); D. Fiott, As you were? The EU as an evolving military actor, in: The CSDP in 2020. The EU's legacy and ambition in security and defence, ed. D. Fiott, European Union Institute for Security Studies (EUISS), Paris 2020, p. 117.

ing middle class), it still remains the most unstable continent. At the same time, dynamic urbanisation or digitisation in Africa (a phenomenon of the last 10 years), apart from the obvious benefits associated with these processes, also carries new challenges and threats, which will not remain without effect on the character and type of EU military operations. Hu- 
manitarian concerns as well as the inclination to support African countries in their subsequent processes of democratisation and post-war/conflict reconstruction are also vital factors behind EU military operations. The still vivid relations between France and its former colonies are worth highlighting, along with the fact that it is France that shapes the EU's expeditionary policy to a great extent.

\section{EU Military Operations - Their Evolution and Main Trends}

Pursuant to the analysis of the ten EU military operations conducted to date in Sub-Saharan Africa, it is necessary to point out some common features of those operations/missions, as well as their evolution and trends related to their further development. The foregoing shapes a specific model related to the functioning of military crisis management operations.

\section{Numbers of Soldiers - From Large to Less Sizeable CSDP Military Operations/Missions}

In the first stage of their functioning (prior to 2010), EU military operations were characterised by the fact that every one of them involved a significant number of soldiers (which definitely distinguished them from civilian missions). This also applied to operations in Sub-Saharan Africa. The first two EU military operations in the DRC (Artemis and EUFOR RD Congo) had an average of 2,000 soldiers. The largest in Africa, and the second largest in the history of the CSDP (after Operation Althea in Bosnia and Herzegovina), in terms of the number of soldiers, is the EU military operation in Chad and the Central African Republic (3,700 troops were deployed). From EUTM Somalia there is a visible downward trend. Military training missions involve fewer personnel, on average around 200 soldiers. Even the combat operation EUFOR RCA accounted for half as many (around 700 soldiers) as the previous EU operations of this type. This state of affairs is perfectly illustrated by the three latest military operations in Africa: EUMAM RCA involves 60 troops, EUTM RCA - 170, and EUTM Mozambique - 140. It seems that this trend will continue in the coming years. At the same time, it should be noted that "numbers of civilian personnel on missions have been fairly stable over the years, although three capacity-building missions (EUCAP Nestor, EUCAP Sahel, EUCAP Sahel Mali) have shown an upward trend". ${ }^{3}$ These

${ }^{3}$ M. Meijnders, D. Zandee, The CSDP in Africa, in: The EU as a security actor in Africa. In-depth study Clingendael Monitor 2016, ed. D. Zandee, Netherlands Institute of International Relations "Clingendael”, The Hague 2015, p. 33. 
three civilian missions are comparable in the number of personnel engaged in the EU military training missions at Central African Republic (CAR). It also seems to be a constant trend in the development of CSDP military operations/missions.

\section{Duration - From Short-Term Operations to Long-Term Military Training Missions}

All of the EU military combat operations conducted so far (except EU NAVFOR Atalanta) were of a short-term mandate, ranging from 3 months (Artemis) to just over a year - EUFOR Tchad/RCA and EUFOR RCA (see Table 1). The state of affairs seems reasonable from the Member States' perspective involved in such activities. If there is a military operation with an executive mandate in the future, the situation will not change. One should agree with the thesis that there is "correlation between the duration of a CSDP operation and the type of mandate: the operation's duration is inversely proportional to the risk that is taken". ${ }^{4}$ The duration of military training missions, however, is comparable to that of civilian missions. They are long-term and their mandate is renewed every two years. ${ }^{5}$ They "are situated relatively low down in the spectrum of violence", ${ }^{6}$ hence the greater tolerance on the part of the Member States for such long-term missions.

\section{Geographical Scope-From Single-City to Single-Purpose Operations}

EU combat operations were geographically limited to one strictly defined area in their mandates, usually the capital city of a given country or region where the operation was stationed. Operation Artemis was limited to the capital of Ituria Region - Bunii. EUFOR RD Congo focused on Kinshasa and the mandates of EUFOR RCA and EUMAM RCA were limited to the country's capital - Bangui. The exceptions to the rule were two EU combat operations - EU NAVFOR Atalanta and EUFOR Tchad/ RCA. The first one was due to its marine, off-shore character. In the latter case, the EUFOR Tchad/RCA forces were deployed in several bases and did not focus solely on supporting or protecting a small territory.

4 Ibidem, p. 34.

5 EUMAM RCA was an exception - but it resulted from the fact that from the very beginning, the mission aimed at being temporary and preparatory prior to a much more sizeable and more complex EUTM RCA.

${ }^{6}$ M. Meijnders, D. Zandee, op.cit., p. 33. 
One researcher noted that "the actual purpose of the mission, i.e., to deter potential rebel groups by military means, shows an evolution in the EU's approach to resolving political conflicts with military tools". ${ }^{7}$ But the evolution seems to have been a one-off. In the case of military training missions, the geographical context no longer plays such a significant role. EUTM Somalia, in its first phase of operation, was an exception in that respect, and the fact that it was not stationed in Somalia in 2010-2012 had a negative impact on the success of the mission. ${ }^{8}$

\section{Object Scope - From Combat Operations to Military Training Missions}

The first four EU military operations were of a combat nature (Artemis, EUFOR RD, EUFOR Tchad/RCA, and Atalanta). They were perceived as a symbol in the EU's pursuit to shape and develop the military component at the EU level. They were the EU's main course of action as regards CSDP crisis management. Civilian missions remained somewhat overshadowed by military operations. EUTM Somalia initiated military non-combat training missions which became one of the permanent elements of the CSDP, also with regard to Africa. They constituted a departure of the EU from its ambitious military objectives that were nonetheless still pursued at the turn of the century. The ultimate goal of the European Union Training Mission is to support the reform and formation of local armed forces to safeguard peace and stability. At the same time, EUTM missions do not require the involvement of as many soldiers as in the case of typical combat operations. Activities under military training missions align with the latest operational activity of the EU - narrowly specialised missions on a relatively small scale, of no combat nature but with a complementary function in stabilising security in the African region - in relation to other tools at the disposal of the EU, as well as in relation to other international and domestic actors/ entities. $^{9}$

7 P. Frankowski, I. Słomczyńska, Unia Europejska - Afryka Subsaharyjska. Uwarunkowania. Mechanizmy. Efektywność wspótpracy, Lublin 2011, p. 187.

8 Mission Headquarters as part of the first two EUTM mandates were located in Kampala. It was also in Uganda where the training camp for the purpose of the mission was set up. The reasons behind organising the mission in Uganda, and not Somalia, were mainly security-related.

9 K. Rękawek, M. Terlikowski, EU CSDP in the Light of the Crisis in Mali, "PISM Bulletin”, 5 March 2013, no. 21(997), p. 2. 


\section{Objectives - From Humanitarian and Stabilisation to EU Security-Related Missions}

The objectives of the first three EU military operations (Artemis, EUFOR RD, and EUFOR Tchad/RCA) focused on issues related to the improvement of the humanitarian situation, the safety and security of civilians - in particular refugees and internally-displaced-persons (IDPs), as well as UN and NGO personnel. As noted by T. Palm and B. Crum, the goals of these operations fall under the normative character of the EU's activity in international relations. ${ }^{10}$

Since Operation Atalanta, attention should be paid to a certain evolution of the objectives adopted by individual military operations/missions. New goals related to combating piracy and international terrorism, as well as guaranteeing the safety and security of the EU (both in the economic and political dimension) arise. This situation is determined to a great extent by a paradigm shift in EU policy. Security issues are becoming a priority, also with regard to the objectives pursued by the EU's military operations and missions. Extremely significant was the 2016 visit of Angela Merkel, as the first chancellor of Germany, to Mali and Niger - vital to the EU from the terrorism and migration vantage point.

CSDP military operational activities towards Africa are, to a much greater extent, based on the "containment" strategy, ignoring the political sources of the conflicts that underpin these problems. The strategy objective is: "firstly, limited military operations targeting terrorist groups; secondly, overt and covert cooperation with governments in the region to stem migrant flows, strengthen local security structures, and keep weak states afloat; and, thirdly, turning to the UN and African regional organisations to run major stabilisation missions and deliver large-scale humanitarian assistance". ${ }^{11}$

\section{Partnership With the UN, NATO, and Regional Organisations}

The EU's military operations and missions are strictly related to the international activity of the United Nations and international regional organisations. They act as their support or complement their activities. The said collaboration stems from the principle of effective multilateral-

10 T. Palm, B. Crum, Military operations and the EU's identity as an international security actor, "European Security", vol. 28(4)/2019, pp. 513-534.

11 R. Gowan, Bordering on Crisis: Europe, Africa, and a New Approach to Crisis Management, "Policy Brief", April 2017, European Council on Foreign Relations, p. 4. 
ism in its external relations promoted by the EU. Operation Artemis of 2003, ${ }^{12}$ EUFOR Tchad/RCA of 2008-2009 and EUFOR RCA of 2014-2015 are bridging operations ${ }^{13}$. The main purpose of Operation Artemis was to provide support to the MONUC (United Nations Organization Mission in the Democratic Republic of the Congo) mission in the DRC, which had been conducted since 1999. The main objective of EUFOR Tchad/ RCA, however, was to ensure the protection and security of all aspects of the UN's presence in eastern Chad and in the north-eastern part of the Central African Republic. That applied to two UN missions - MINURCAT and the African Union/United Nations Hybrid Operation in Darfur - UNAMID. Once its annual mandate had been fulfilled, the EUFOR RCA operation handed over the assignment to the United Nations Multidimensional Integrated Stabilization Mission in the Central African Republic (Mission internationale de soutien à la Centrafrique sous conduiteafricaine).

The cooperation between the EU military training missions and regional organisations (and missions authorised by them) is of particular importance. They play a crucial role in reintegrating EUTM-trained soldiers into defence forces. In Somalia it was AMISOM, Mali - AFISMA and MINUSMA, and CAR - MINUSCA.

The collaboration of EU NAVFOR Atalanta with the NATO mission in combating Somali piracy should also be emphasised. As C. Gebhard and S.J. Smith point out, "cooperation and coordination between EU and NATO forces has, nevertheless, worked surprisingly well at the operational and tactical levels". ${ }^{14}$ In addition to the collaboration with the

${ }^{12}$ Operation Artemis triggered further collaboration (already institutionalised) between the EU and UN. A few weeks following the cessation of the mission, both entities signed a Joint Declaration on EU-UN Cooperation in Crisis Management. See more: K. Zajączkowski, CSDP missions and operations as instruments of EU crisis management - their essence, role and determinants, "On-line Journal Modelling the New Europe", no. 34/2020, pp. 12-13.

13 "The bridging model is one of the scenarios for UN - EU cooperation in crisis management. It describes a situation where an EU led operation intervenes first and paves the way for a handover to a UN operation". CSDP Missions and Operations: Lessons Learned Processes, Directorate-General for External Policies of the Union Directorate B Policy Department Study, European Parliament, April 2012, p. 81.

${ }^{14}$ Operation Atalanta provides more possibilities than a NATO mission. It applies mainly to the issue of evidentiary and court proceedings against persons charged with piracy. The EU has signed relevant cooperation agreements in that regard with individual African countries. NATO does not have any such agreements. What is more, the EU in its anti-piracy policy, has a number of instruments at its disposal, not necessarily related to the CFSP and CSDP. Therefore it is of a more complex nature as compared to NATO. The EU's advantage may be proven by German's stance 
NATO mission, the EU coordinates its activities with other units/operations conducting their missions off the coast of Somalia, as well as, inter alia, with The United Nations Office on Drugs and Crime - UNODC as regards creating appropriate conditions in the countries of the Horn of Africa that would allow for fair trials of people arrested for piracy, or with The Contact Group on Piracy off the Coast of Somalia - CGPCS. According to D. Helly, in the second decade of the 21 st century, "with over 20 nations and two dozen international vessels patrolling in the area the region has become a laboratory for international military naval coordination", ${ }^{15}$ as well as for the EU.

\section{France - The Leading Country}

France was either the initiator or co-initiator of all hitherto military operations and missions in Africa. Commenting on France's involvement (incommensurate with the contribution of other EU countries) in the first EU military operation in Africa, T. János noted that "while it ultimately received an EU badge, its origin, command and control were French". ${ }^{16}$ From a near 20 year perspective, it should be stated that little has changed and this comment would apply to most of the conducted (or ongoing) EU military operations. This state of affairs stems, on the one hand, from France's interests and its foreign policy goals (global, European, and African), and, on the other, from the lack of political will of other Member States to become more involved in these operations, as well as the specific reluctance of Member States to show European solidarity with France's security policy objectives.

As regards France's strategic goals, G.R. Olsen emphasises that Operation Artemis was "France's opportunity to confirm its position as a militarily effective global participant in international relations". ${ }^{17}$ From the

and the withdrawal of their contingent from NATO's naval forces to join Operation Atalanta. The UK (still as a member of the EU) unequivocally supported Operation Atalanta - reasoning it with judicial cooperation agreements signed by the EU with African countries. C. Gebhard, S.J. Smith, Beyond Rivalry? EU-NATO Cooperation in Counter-Piracy Operations, http://piracy-studies.org/2014/beyond-rivalry-eu-natocooperation-in-counter-piracy-operation; C. Gebhard, S.J. Smith, The two faces of EU-NATO cooperation: Counter-piracy operations off the Somali coast, "Cooperation and Conflict", vol. 50(1)/2015, pp. 107-127.

15 D. Helly, EU NAVFOR Somalia, in: ESDP: The first 10 years (1999-2009), eds. G. Grevi, D. Helly, D. Keohan, EU Institute for Security Studies 2009, Paris, p. 398.

16 T. János, Operation “Artemis": The First Autonomous EU-led Operation, "AARMS", vol. $14(1) / 2015$, p. 121.

17 G.R. Olsen, The EU and Military Conflict Management in Africa: For the Good of Africa or Europe?, "International Peacekeeping”, vol. 16(2)/2009, p. 251. 
perspective of structural realism, C. Gegout also draws attention to the very same fact as he highlights that "with Artemis, France also succeeded in demonstrating its own defence capabilities. (...) It could be recognised politically as an effective military actor". ${ }^{18}$ Other EU military operations in which France played a leading role also served to build and strengthen its international position.

As regards the European dimension, France, through EU military operations, has aimed to balance US power in line with the balance of power theory. "France badly wanted a mission to show the EU was capable of acting alone, where NATO would not be involved". ${ }^{19}$

As for African objectives, the EU's military operations serve to restore France's position in some parts of Africa (as in the case of the DRC) or to maintain the status quo and thus its influence (as in the case of Chad).

France's activity in Mali and the CAR reaffirmed a certain pattern. Since the presidency of F. Holland, France has avoided endorsing another incarnation of Franceafrique. Hence, France's unilateral operations there have been complemented by EU military operations, ${ }^{20}$ and therefore can observe a specific Europeanisation of Paris' activities on the African continent. French soldiers are deployed alongside EU forces under the EU flag. ${ }^{21}$ For Paris, such a tactic has been beneficial, as it has allowed them to avoid possible accusations of neo-colonialism. What is more, memories of the failed intervention in Rwanda (1994) are still extremely controversial in France and to a great extent define the priorities of its policy in Africa. President E. Macron has continued that policy and, in 2017, declared that he was from a "generation that does not come and tell Africa what to do".22

\section{A Tool in the EU's Toolbox}

The EU's military operations and missions in Africa constitute only one of the crisis management instruments of the European Union and its broader involvement in the resolution of international conflicts. This is reflected in the integrated and comprehensive approach of the EU in

${ }^{18}$ C. Gegout, Causes and Consequencs of the EU's Military Intervention in the Democratic Republic of Congo: A Realist Explanation, "European Foreign Affairs Review", vol. 10(3)/2005, p. 437.

19 Ibidem, p. 437.

20 B. Sixdenier, Stability spectrum: the battle for stabilization in the Central African Republic, "IRSEM Research Paper", no. 42, 6 July 2017, p. 5.

${ }^{21}$ N.I.M. Nováky, From EUFOR to EUMAM: The European Union in the Central African Republic, "European Foreign Affairs Review”, vol. 21(1)/2016, pp. 99-100.

${ }^{22}$ France's reset in Africa, "The Economist”, 05-11 June 2021, pp. 33-34. 
external relations, which is characterised by: a security-development nexus, civilian-military synergies, an internal-external security nexus and is based on combining political, economic, and development activities with the military ones.

Operation Artemis and EUFOR RD Congo gave rise to the European Union's commitment to reconstruct the country, which has been ongoing for almost twenty years. The EU has been the largest donor of development assistance to the DRC, and the EU civilian missions conducted in this country have somewhat complemented the EU's first combat operations in the DRC. EUTM Somalia and Operation Atalanta, in addition to the civilian mission Nestor, should also be considered solely and exclusively in the context of the EU's overall approach to the problems of Somalia and the region, as reflected in the Strategy for the Horn of Africa adopted by the EU in 2011 and the appointment of the EU Special Representative for the Horn of Africa. The EU military operation in Mali is also part of the EU's activities for the benefit of the entire Sahel region, launched under the Security and Development Strategy adopted in March 2011. Besides EUTM Mali, civilian missions launched by the EU in the region such as EUCAP Sahel Niger and EUCAP Sahel Mali should be highlighted, as well as activities providing assistance (the EU is the largest donor to Mali and the region), and the appointment of a Special Representative for the Sahel. In its endeavours to stabilise the situation in CAR, the EU also applies several instruments simultaneously, from development assistance and humanitarian aid to military missions. In conclusion, CSDP military operations and missions have "become an important instrument in the EU's external action toolbox". ${ }^{23}$

\section{The Main Weaknesses and Challenges Limited Operation Mandate, No Use of Battle Groups, and No Headquarters}

Military operations conducted hitherto have been viable due to the fact that their geographic, subject, and time scope was extremely limited. There is no consent nor political will among the EU Member States to expand their territorial reach or their competences. According to C. Gegout "EU military intervention could be explained by maximal realism, as it was made on a lowest common denominator agreement after evaluating the costs and benefits of an intervention". ${ }^{24}$ The researcher also emphasises

${ }^{23}$ The EU and the world: players and policies post-Lisbon. A handbook, ed. A. Missiroli, EU Institute for Security Studies, Paris 2016, p. 48.

${ }^{24}$ C. Gegout, op.cit., pp. 435-436. 
that "the morality issue is thus, as assumed by maximal realists, only considered when there are very few casualty risks for European troops". 25

On the other hand, based on the assumptions of new liberalism, B. Pohl argues that governments, faced with a decision to either send or not send a contingent as part of the CSDP mission/operation, must "pre-empt the twin dangers of standing accused of pointless activism and excessive risktaking or complacency and weakness" ${ }^{\prime 26}$ with their actions. It is the internal pressure the governments are subjected to that explains the fact that EU military operations avoid risks, are limited in time, and generally are not very ambitious.

The lack of consent to use battle groups as part of the EU military operations has a significant effect on the scope of their activities, which somewhat proves the weakness in the development of the CSDP. Member States decided not to use battle groups in Chad in 2008, nor to stabilise the situation in Mali in 2013 nor during CAR operations in 2014, even though the nature of the conflict as well as the objectives set out for the EU missions aligned perfectly with assignments for battle groups. To paraphrase the words of $\mathrm{D}$. Cristiani, it can be said that in the context of military crisis management operations "an outright EU military option was never seriously considered". ${ }^{27}$

It should also be emphasised that the mere determination of the final shape of a military mission or operation usually required Member States to conduct several rounds of negotiations. For instance, the consensus on the operational capacity of EUFOR Tchad/RCA was reached only after 5 rounds of negotiations. In the case of EUMAM RCA, however, as many as four force generation conferences were required to determine the final shape of the mission. ${ }^{28}$

N. Nováky draws attention to certain paradox as regards EUFOR RCA and EUMAM RCA operations/missions, although such attention should be drawn to every EU-organised military operation/mission. He emphasises that: "on the one hand, their planning processes were quick and effective; on the other hand, their force generation processes were prolonged and difficult". ${ }^{29}$ According to the researcher, "in the case of both missions, there was a mismatch between EU Member States' desire to

25 Ibidem, p. 440.

26 B. Pohl, The Logic Underpinning EU Crisis Management Operations, "European Security", vol. 22(3)/2013, p. 318.

27 D. Cristiani, The Malian Crisis: Causes and Dynamics, in: The EU's External Action Service: Potentials for a one voice Foreign Policy, eds. D. Dialer, H. Neisser, A. Opitz, Innsbruck 2014, p. 141.

${ }^{28}$ N.I.M. Nováky, op.cit., pp. 110-112.

${ }^{29}$ Ibidem, p. 95. 
act and their willingness to invest resources in those actions, that is, an intentions-reality gap". ${ }^{30}$

To date, no permanent command of military operations (Headquarters) has been established (as opposed to civilian missions). Military Planning and Conduct Capability (MPCC) will lead only EU non-executive military missions, i.e., military training missions. The situation affects the effectiveness of combat military operations.

\section{A Limited Scope of Operations vs. the Stabilisation Process; the (Un)sustainability of Peacekeeping and Training Activities}

The limited mandate of individual EU military operations determines their limited impact on the stabilisation process and the sustainability of the European Union's peacekeeping activities.

In the case of Operation Artemis, it is highlighted that while the EU and the international community focused on the town of Bunia, killings, ethnic cleansing and violence continued in the rest of Ituri. As one witness described it, "Ituri was covered in blood". ${ }^{31}$ In addition, new massacres erupted in the area shortly after the departure of the force. In this context, C. Gouget remarked: "If actorness is considered as being recognised as a capable power, the EU succeeded in its limited mission in Bunia. But if actorness is considered as projecting humanitarian values and reacting to a grave humanitarian crisis, then the EU failed in the DRC" 32 is particularly appropriate.

The subsequent EU military operation in the DRC (EUFOR RD) also had a limited impact on the situation in the country. "The operation cannot be considered an example of dealing alone with serious military challenges". ${ }^{33}$ Firstly, it is highlighted that in comparison with the destruction the country sustained during the war as well as its size (it's three times larger than France), the contingent deployed was extremely deficient and was stationed only in the country's capital. In practice, according to B. Górki-Winter, it would be virtually impossible to ensure security in the event of more serious unrest outside the capital of the country. ${ }^{34} \mathrm{Sec}-$

30 Ibidem.

31 T. János, op.cit., pp. 121, 127.

32 C. Gegout, op.cit., p. 435.

33 C. Major, EUFOR RD Congo, in: ESDP: The first 10 years (1999-2009), eds. G. Grevi, D. Helly, D. Keohan, EU Institute for Security Studies, Paris 2009. p. 322.

34 B. Górka-Winter, Misja Unii Europejskiej w Demokratycznej Republice Konga (EUFOR RD Congo), "Biuletyn PISM”, no. 384/2006, p. 2. 
ondly, it is emphasised that the mandate of the EU was rather of a limited timeframe, and did not account for the post-election period, even though France and Belgium applied for its extension several times. ${ }^{35} \mathrm{~J}$. Howorth points out that the mission ceased exactly when it was needed the most, i.e., when the election results were announced (after the displacement of EU forces, the Republican Guard supporting President Kabila attacked the personnel responsible for protecting the leader of opposition, which resulted in the deaths of 300 people). ${ }^{36}$

Operation EUFOR Tchad/RCA also does not cover all geographical areas and does not have police or judiciary powers. D. Helly highlights that "strong mandate focused on civilian and aid workers protection, with clearly defined rules of engagement, but did not provide the mission with enough guidance and strength to manage initial political ambiguities". ${ }^{37}$ The EP report, however, emphasises that "EUFOR Tchad/RCA was designed as an end-date rather than an end-state operation meaning that its exit strategy was related to a specific date rather than to a change in the security conditions on the ground". ${ }^{38}$

Operation Atalanta, which must be considered a success and which has proved effective in combating piracy at sea, also shows a "failure to address the key causes of piracy (...). No significant planning and command structures responsible for the previous increase in pirate attacks have been eradicated". ${ }^{39}$

Operation EUFOR RCA was, similarly to other EU operations, far too short for the challenges and perils in the CAR. Its replacement with EUMAM and EUTM RCA, which engaged even fewer personnel and were of different nature, "raises questions over the sustainability of what the EU has achieved once it pulls out". ${ }^{40}$

As regards EU military training missions, there are serious doubts about the sustainability of their activities, which mainly concern whether EU-trained units of the Malian, Somali, or Central African armies will be able to take over the responsibility for safeguarding the territorial integrity of their countries and protect them against asymmetric threats (mainly terrorism and organised crime).

${ }^{35}$ CSDP Missions and Operations: Lessons Learned..., op.cit., p. 73.

${ }_{36}$ J. Howorth, Security and Defence Policy in the European Union, Basingstoke 2007, p. 239.

${ }^{37}$ D. Helly, EUFOR Tchad/RCA in: ESDP..., op.cit., p. 347.

${ }^{38}$ CSDP Missions and Operations: Lessons Learned..., op.cit., p. 81.

39 J. Raubo, Operacja wojskowa EUTM SOMALIA, in: Operacje wojskowe Unii Europejskiej w Afryce, ed. B. Przybylska-Maszner, Poznań 2014, pp. 180-181.

40 T. Tardy, EUFOR RCA: tough start, smooth end, "Issue Alert" 2015, March, European Union Institute for Security Studies, p. 2. 
The situation in the Somali armed forces is perfectly illustrated by the headline of one of the newspapers, which read: "Somalia's future relies on an army that does not yet exist". ${ }^{41}$ "Although the training of more than 3,000 soldiers and officers by the European Union Training Mission has contributed considerably to their capability, the SNA continues to lack operational capacity in terms of skills and equipment". ${ }^{42}$

Another example confirming the concerns about the sustainability of EU activities was the unsuccessful attempt to recover the city of Kidal by the Malian army from the hands of Tuareg organisations united under the banner of the National Movement for the Liberation of Azawad (MNLA) in May 2014. As noted in one of the reports: "Given the value of EUTM's contributions, which no one contests, Kidal makes clear that EUTM simply is not sufficient if the goal is getting Mali's army to the point where it can conduct the mission of being able to mount a complex attack against a fixed position at a great distance". ${ }^{43}$

The still unstable situation in Mali (a double coup occurring in 2020 and 2021) and in Somalia clearly shows that the military structures in those countries are weak and the activities of the EU (and other international organisations) to reconstruct them are limited.

\section{Equipment Deficiencies}

All EU military missions/operations to date have encountered problems with air transportation. In the case of Operation Artemis, France had to enter into an agreement with Ukraine to rent AN-124 aircraft (during the mission they conducted 43 flights in total). ${ }^{44}$ "EUFOR RD Congo also faced constraints in the realm of airlift, where it was two aircraft short of the capabilities requested during the planning phase". ${ }^{45}$ Air transportation problems were also encountered during operation EUFOR Tchad/ RCA, which eventually required negotiations with Russia as regards the rental of 4 helicopters. According to analysts, "logistics should receive

${ }^{41}$ M. Fitzgerad, Somalia's future relies on an army that does not yet exist, "The Irish Times", Nov 4, 2013, https://www.irishtimes.com/news/world/africa/somalia-s-future-relies-on-an-army-that-does-not-yet-exist-1.1582453 (access 25.11.2021).

42 Somalia SSR Background Note, http://issat.dcaf.ch/Learn/Resource-Library/ Country-Profiles/Somalia-SSR-Background-Note (access 25.11.2021).

${ }^{43}$ M. Shurkin, S. Pezard, S.R. Zimmerman, Mali's Next Battle. Improving Counterterrorism Capabilities, London 2017, p. 100, https:/www.rand.org/content/dam/rand/ pubs/research_reports/RR1200/RR1241/RAND_RR1241.pdf (access 25.11.2021).

44 "In fact, the only real access to Ituri's main town was a small, rough and ready airstrip, accessible only by a C-130 Hercules or a C-160 Transall tactical transport aircraft”. T. János, op.cit., p. 127.

${ }^{45}$ C. Major, op.cit., p. 316. 
greater attention in the pre-planning phase in order to anticipate national limitations (e.g., air transport) at an early stage". ${ }^{46}$

The fact that there was an insufficient number of ships dedicated to the EU NAVFOR operation should also be emphasised. Even though the patrolling area is constantly expanding, Member States are sceptical about increasing the fleet and thus incurring additional costs. Moreover, "vessels for the EU NAVFOR operation were constructed primarily with classic naval functions in mind, therefore are less suited to combat piracy". ${ }^{47}$

\section{Nowhere Without France}

Without France's military, political, and financial commitment, EU military operations seem questionable. As one of the researchers notes, "without assertive leadership from France it seems unlikely that the mission would have been approved in Brussels". ${ }^{48}$ Moreover, a favourable factor for the implementation of military operations by the EU in Africa was the possibility to take advantage of the military infrastructure that France has had at its disposal in several African countries (Djibouti, Gabon, and Chad). ${ }^{49}$

The mission in Mali is an example that illustrates France's role and significance in the process of shaping a mission. Member States "were unable to come to a decision with regard to setting up a mission before it was clear which forces would take over the main assignment of stabilising the security situation in Mali and, indirectly, also protecting the personnel of EU operations". ${ }^{50}$ This pattern is similar to the crisis in Chad in 2008 and in shaping other EU military operations. The EU did authorise a joint military mission after having been convinced that France would be the one to make the main military, financial, and logistical contribution to the mission. ${ }^{51}$ D. Cristiani and R. Fabiani point out that EUTM Mali "can hardly be considered 'European', despite the shared goals amongst Member States, given the limited support to France provided by other EU Member States". 52

${ }^{46}$ CSDP Missions and Operations: Lessons Learned..., op.cit., p. 81.

47 J. Raubo, op.cit., p. 181.

48 C. Gegout, op.cit., p. 435.

49 A. Ciupiński, Wspólna polityka bezpieczeństwa i obrony Unii Europejskiej. Geneza, rozwój, funkcjonowanie, Warsaw 2008, p. 248.

${ }^{50}$ K. Rękawek, M. Terlikowski, op.cit., p. 2.

51 M. Eilstrup-Sangiovanni, The EU's Common Security and Defence Policy and the Mali Crisis, 16 August 2013, http://www.e-ir.info/2013/08/16/the-eus-common-security-and-defense-policy-and-the-mali-crisis (access 25.11.2021).

${ }^{52}$ D. Cristiani, R. Fabiani, From Disfunctionality to Disaggregation and Back? The Malian Crisis, Local Players and European Interests, "IAI Working Papers", no. 1308, March 2013, p. 14, http://www.iai.it/sites/default/files/iaiwp1308.pdf (access 25.11.2021). 
In this context, D. Helly states: "this predominant French role raises a fundamental question: are ESDP military operations, in Africa and elsewhere, possible without France acting as the main initiator and framework nation?". ${ }^{53}$ The question seems rhetorical.

Operation EUFOR RCA, the EU's latest military operation with a combat mandate hitherto, would not have been possible without France's involvement. It was Paris that initiated EUFOR RCA and was the framework nation.

\section{The Financing of Military Operations}

Financial issues significantly prevent Member States from being directly engaged in EU military operations/missions, particularly since some European countries have reduced their budgetary spending on the military. One of the officers explained quite vividly the issue of the costs as regards EU military operations via the example of EU activities in the CAR: "if it costs $\mathrm{x}$ euros to send a soldier to Kosovo, it costs $2.5 \mathrm{x}$ to send one to Afghanistan and 3.5x to the CAR. Thus, some Member States simply could not afford to participate in EUFOR". ${ }^{54}$

It should be emphasised that the expenditures of EU military operations are financed from the EU Athena mechanism to an insignificant extent (around 20\%) only. Most of the costs are borne by the countries directly involved in the operation.

During Operation Artemis, France incurred the majority of the financial (c. EUR 46.5 million of its own costs) as well military costs of the operations. The common costs of operation EUFOR RD Congo, pursuant to the Athena principles, amounted to EUR 23 million, the remaining expenditures as part of individual costs were covered by the states engaged in the mission, including primarily France - EUR 27 million and Germany - EUR 26 million. The common cost of operation EUFOR Tchad/ RCA was EUR 119.6 million and total expenditure is estimated at EUR 1 billion. France assumed the main burden of financing the mission $(80 \%$ of the total cost).

\section{A Comprehensive Approach - Objectives Still Not Met}

The effectiveness of a mission/operation's impact in a given region is related to the coherence of EU decisions and activities as regards external relations. Despite action being taken in that respect, the lack of coherence

\footnotetext{
53 D. Helly, EUFOR Tchad/RCA in: ESDP..., op.cit., p. 350.

${ }^{54}$ N.I.M. Nováky, op.cit., p. 103.
} 
remains one of the main challenges in the EU's international activity. There is also no comprehensive strategy to use CSDP operations/missions for broader external activities of the EU. One should also bear in mind the dichotomous division of the EU's external relations into that of the economic (pursuant to the community principle) and political (based on intergovernmentalism).

The inconsistency applies to a number of activity areas related to EU military operations. It encompasses the relationship between a given military operation and the European Commission. Operation EUFOR Tchad/ RCA is a very good example. On the one hand, "the Commission had been involved since beginning of the Council's planning process, hence the 'comprehensive planning' of the EUFOR Tchad/RCA was described as an 'internal milestone for the EU'". ${ }^{55}$ On the other hand, the partnership between the operation and the Commission was suboptimal. The tense relations between the operation commander and the head of the EC delegation were not conducive to obtaining coherence. ${ }^{56}$

The inconsistency relates to the interoperability as part of a given operation. The factor that hindered the functioning of EUFOR RD Congo was the significant differences in the legal regulations of individual national subunits and diverse rules of engagement.

"The civil-military nexus and internal-external security nexus raised also a set of challenges regarding the coordination between actors coming from different organizational and institutional cultures. Civilian actors and militaries should learn to work together, notably in operation planning, but different skills, means, methods, perceptions of security and threats as well as purposes and logics of action make this difficult". 57

An additional problem in the context of a comprehensive approach implementation by CSDP operations is the fact that they were extremely one-dimensional. These operations focus excessively on security issues. D. Cristiani and R. Fabiani, while analysing EUTM Mali, note that "the EU's major preoccupation has been the eradication of the terrorist threat". ${ }^{58}$ When referring to the EU NAVFOR Atalanta, however, it is em-

${ }^{55}$ CSDP Missions and Operations: Lessons Learned..., op.cit., p. 82.

56 "The delegation of the Commission partly shared some of the humanitarian community's concerns regarding the role of EUFOR and, while in charge of supporting internal political dialogue, viewed the military operation with some mistrust". D. Helly, EUFOR Tchad/RCA, in: ESDP..., op.cit., p. 347.

57 Ch. Lavallée, J.C. Völkel, EU security governance in the Sahel region: Implementing a multidimensional strategy in an unstable environment, Paper, presented at the IPSA Annual Conference Montreal, 21 July 2014, p. 17.

${ }_{58}$ D. Cristiani, R. Fabiani, op.cit., p. 13. 
phasised that piracy is not merely a maritime problem, and the mission itself "suffers from a deficit of land operations" in both the political and strategic as well as social and economic dimensions. In the first case, it applies to such issues as: insufficient intelligence reconnaissance on land, and inadequate judicial and prosecutor collaboration with the countries from the region. In the latter case, it should be highlighted that the regions which obtained significant ransom profits in previous years, failed to receive a real alternative from the local authorities. Therefore, as one of reports indicates: "as long as the benefits outweigh the risks, so long will the pirates continue their activity". ${ }^{59}$ One of the analyses quite accurately and aptly noticed that the slogan "Piracy first" must be replaced with a broader and more comprehensive - "Somalia first". ${ }^{60}$ Otherwise, it will only be possible to talk and write about a partial victory over piracy along Somalia's east coast.

Some researchers refer to the foregoing phenomena and tendencies in military operations and missions as the "security belt" approach. By the same token, the simplistic approach to the issue of security in Africa is adopted. "Current military and civilian crisis management operations appear to focus largely on scoring easily quantifiable short-term results rather than addressing the complex political factors which are often overlooked by European policymakers but which both favour migrant traffickers and terrorists". ${ }^{61}$

Some weaknesses related to the cooperation with local people and the fact that local expertise is not actually used to a great extent are also highlighted. In this context, military operations should, as indicated in one of the reports, take into account local and political conditions (e.g., local, cross-border, and regional political challenges), and their representatives should "anticipate and engage early in looming conflict crises". 62

\section{Climate Change, Technologies, Urbanisation, and the Execution of Military Operations}

The new challenges that emerged in the second decade of the 21st century will affect the subsequent course of EU military operations and

${ }^{59}$ H.G. Ehrhart, K. Petretto, The EU and Somalia: Counter-Piracy and the Question of a Comprehensive Approach, Study for The Greens/European Free Alliance, Hamburg, February 2012, p. 35.

${ }^{60}$ Ibidem, p. 1.

61 R. Gowan, op.cit., p. 4.

62 Ibidem, p. 10. 
missions. In one of the reports from the European Union Institute for Security Studies, ${ }^{63}$ G. Lindstrom distinguishes three of, in his opinion, the most important ones. These are: climate change, urbanisation, and new technologies. It is believed that those processes, along with the consequences they entail, besides affecting the social, economic, and political development of countries or regions, including Africa (where the EU deploys the majority of its military operations/missions), will also mean that EU operations/mission will have to adapt to the new conditions.

As regards climate change, one should bear in mind that 7 out of 10 of the most affected countries will be from Africa. The said changes will result in greater instability in the African continent, determine the intensifying migrations within the continent, and cause conflicts and disputes over food and water. Therefore, military operations/missions in their objectives and operational plans will have to account for the above-mentioned phenomena to a greater extent than ever before.

As regards urbanisation, "the United Nations 2018 World Cities report projects that 28 cities will cross the five million mark at some point between the present and 2030. Of these, thirteen are located in Asia and ten in Africa" ${ }^{64}$ EU missions/operations currently focus on activities in less urbanised and less populated areas. The rapid process of urbanisation of African countries will force future operations/missions, including military ones, to be better prepared for operational activities not only in cities, but also in densely populated areas, and in urban architecture (e.g., narrow, winding streets).

The development of new technologies and their use by military forces, rebels, and terrorists will also affect EU operational activities. It is indicated that military operations, to a greater extent than before, must take into account in their operational plans such issues as: drone application (both by missions/operations and by adverse parties), cyber-attacks on the infrastructure of operations/missions and on the region where the EU mission/operation will be stationed; and AI usage for operational activities.

${ }^{63}$ G. Lindstrom, Emerging security challenges. Four futures for CSDP, in: The CSDP in 2020. The EU's legacy and ambition in security and defence, ed. D. Fiott, European Union Institute for Security Studies (EUISS), Paris 2020, pp. 88-96.

${ }^{64}$ Ibidem, p. 90; United Nations, Department of Economic and Social Affairs, Population Division, The World's Cities in 2018-Data Booklet (ST/ESA/ SER.A/417), 2018, https://www.un.org/en/events/citiesday/assets/pdf/the_worlds_cities_in_2018_ data_booklet.pdf (access 26.11.2021). 


\section{The (Non)credibility of the $\mathrm{EU}$}

France's role in shaping the EU's expeditionary policy, affects the position and role of the European Union itself. EU training operations or missions in regions where they are stationed are usually perceived as French operations, not European initiatives, which is often abused by the parties directly involved in the conflict. For instance, the rebels perceived the EUFOR Tchad/RCA mission as being supplementary to government forces rather than as a stabilisation and peacekeeping mission. This significantly weakened the position of the EU and prevented it from playing the role of mediator/arbiter in the conflict. The European Union lacks a certain credibility. Another example is the EU's activity in the Horn of Africa, which is viewed there as a US ally in the fight against terrorists, despite its significant importance in development and humanitarian policy. This sort of EU activity is, however, overlooked. The "militarisation" of EU activities and its approach referred to as the "security belt", as mentioned hereinabove, compounds this perception. ${ }^{65}$

\section{EU Military Operations. Towards a Security Actor? - A Theoretical Perspective}

Military operations shape the EU's position as an actor in crisis management and conflict prevention in international relations. At the same time, these operations and missions are part of the EU's international strategy, which is based on the concept of the EU as a non-military and normative power. In this context, the literature on the subject raises a question about the relationship between EU military operations and the above-mentioned concepts. Defensive liberals generally respect the principle of non-interference in internal affairs. They dogmatically repeat I. Kant's words: "no state shall by force (militarily) interfere with the constitution and government of another state". ${ }^{66}$ They, however, justify (not mandate as offensive liberals) external military interventions to prevent serious human rights violations such as genocide. Such intervention, though, must meet several conditions. Firstly, it must be multilateral, i.e., mandated by the Security Council and endorsed by the international community. Secondly, it can only be launched after all other measures,

${ }^{65}$ M. Cathelin, EU's Africa Foreign Policy after Lisbon. Conference Report, Brussels - 18 October 2011, The Observatoire de l'Afrique, p. 4, http://www.obsafrique.eu/wpcontent/uploads/2011/11/Conference-Report_EU-Africa-Foreign-Policy1.pdf (access 26.11.2021).

${ }^{66}$ T.C. Walker, Two Faces of Liberalism: Kant, Paine, and the Question of Intervention, “International Studies Quarterly”, no. 52/2008, p. 450. 
such as international negotiations and sanctions, have been exhausted. Thirdly, its time and scope must be limited. The EU's military missions and operations follow the model presented by defensive liberals. They complement the activities of the United Nations or other international organisations (e.g., the African Union). The main objectives of all EU military operations to date have been the protection of people and the prevention of human rights violation. They are mainly to create conditions conducive to democracy and stability, and not to overthrow tyrants. They fall within the EU's comprehensive approach towards transformation processes in non-democratic countries. ${ }^{67}$

The concept of a non-military power, despite its "civil" nature, is also valuable to analyse the course of CSDP missions and operations. Firstly, all of them only complement EU economic and diplomatic activities in a given region or country (see: the security-development nexus principle). Secondly, the practice hitherto proves that the objectives of EU missions and operations are of civilian nature and they are launched to protect and consolidate fundamental liberal values. Thirdly, EU missions and operations exemplify the principle of "effective multilateralism". ${ }^{68}$

An analysis of the activities conducted to date within the framework of the EU's military operations also demonstrates that there is no contradiction between the concept of the European Union as a normative power (as well as a civilian power) and the tendencies to develop its military dimension. The fact that the European Union launches military operations is not tantamount to renouncing its role as a "civil" and "normative" participant in international relations. I. Manner's claim that the use of military force risks "weakening the EU's peaceful normative power in favour of a stronger and potentially aggressive presence" 69 in the context of EU military operations is unfounded. Two assumptions should be made here: the fact that the EU uses military force abroad depends only on normative and civil (non-military) objectives; EU military operations do not usually have a combat mandate, and the majority of them are training missions. ${ }^{70}$

67 B. Miller, Democracy Promotion: Offensive Liberalism versus the Rest (of IR Theory), "Millennium: Journal of International Studies”, vol. 38(3)/2010, pp. 572-573, 577-578, 588.

${ }^{68}$ S. Stavridis, Why the 'Militarising' of the European Union is Strengthening the Concept of a Civilian Power Europe, "EUI Working Papers", no. 1/2001.

${ }_{69}$ I. Manners, Normative power Europe reconsidered: beyond the crossroads, "Journal of European Public Policy", vol. 13(2)/2006, p. 194.

70 See more: K. Zajączkowski, Misje cywilne i operacje wojskowe Unii Europejskiej w perspektywie wybranych teorii stosunków międzynarodowych i integracji europejskiej, Warsaw 2019. 


\section{Conclusions}

1. The foregoing analysis enables a positive verification of hypothesis no.1 formulated in the Introduction. EU military operations and military training missions should be perceived solely as one of the elements (measures) in the EU's external policy. As it has been highlighted by the title of this article, these are "tools in the EU's foreign policy toolbox". They neither implement strictly military objectives, nor have a driving force, nor make the EU a security actor. Such a term as regards EU military operations is unfounded. Hence, contrary to the what dogmatic representatives of theoretical schools (liberal and constructivist) claim, there is no clash between the EU conducting military crisis management operations and playing the role of a civilian and normative superpower. Irrespective of EU military operations, the development state of CFSP and CSDP does not allow one to define the EU as a fully-fledged security actor. The EU, however, is a vital "security manager"71 since it takes part in every stage of a dispute's resolution. According to A. Menon: "The Union is unique among international organisations in its capacity to contribute to all three aspects of post-conflict stabilisation: security (military and policing), economic and humanitarian, and political and institutional". ${ }^{72}$ An in that very respect, EU military operations should be evaluated, analysed and depicted.

2. One article portrays EU international activity for security in Africa as "peacebuilding by proxy" ${ }^{73}$ The title aptly describes the EU's role on the African continent in that regard, also in terms of military crisis management activities. They complement and support the activities of regional international organisations. Military operations constitute a significant element in the transition from military operations to long-term stabilisation and development endeavours.

3. Actions and initiatives as regards the CSDP reforms have been intensified since 2016. Even though the said reforms to some extent strengthen, especially on the institutional level, the CSDP, they fail to directly translate into the dynamics and shape of EU military operations.

71 D. Fiott, Introduction, in: The CSDP in 2020. The EU's legacy and ambition in security and defence, ed. D. Fiott, European Union Institute for Security Studies (EUISS), Paris 2020, p. 7.

72 A. Menon, Empowering paradise? The ESDP at ten, "International Affairs", vol. $85(2) / 2009$, p. 228.

73 P.M. Norheim-Martinsen, The EU in Africa: peacebuilding by proxy, Noref Report - October 2013, https://www.files.ethz.ch/isn/172333/f486d101d4f46690d710109 f9f466c73.pdf (access 10.11.2021). 
4. Neither the changes announced by the European Commission, nor the Strategic Compass, nor the plans for strategic autonomy will stimulate the EU's activity in terms of military crisis management operations. EU military operations evolve towards training operations. They divert from being combat operational activities to training and consultancy assignments within the CSDP.

5. The EU will not launch large combat military operations, as it was the case prior to 2010. It will focus on less-sizeable, rather technical operations related mainly to new challenges that the EU has to face as regards urbanisation, new technologies or climate change. Hence, hypothesis no. 2, formulated in the Introduction, should also be confirmed.

\section{References}

Cathelin M., EU's Africa Foreign Policy after Lisbon. Conference Report, Brussels - 18 October 2011, The Observatoire de l'Afrique, http://www. obsafrique.eu/wp-content/uploads/2011/11/Conference-Report_EUAfrica-Foreign-Policy1.pdf (access 26.11.2021).

Ciupiński A., Wspólna polityka bezpieczeństwa i obrony Unii Europejskiej. Geneza, rozwój, funkcjonowanie, Difin, Warszawa 2008.

Covid-19 in Africa. At the end of the line, "The Economist", 06-12 February 2021.

Cristiani D., Fabiani R., From Disfunctionality to Disaggregation and Back? The Malian Crisis, Local Players and European Interests, "IAI Working Papers", no. 1308, http://www.iai.it/sites/default/files/iaiwp1308.pdf (access 25.11.2021).

Cristiani D., The Malian Crisis: Causes and Dynamics in: The EU's External Action Service: Potentials for a one voice Foreign Policy, eds. D. Dialer, H. Neisser, A. Opitz, Universität Innsbruck, Innsbruck 2014, DOI: 10.26530/OAPEN_466610.

CSDP Missions and Operations: Lessons Learned Processes, DirectorateGeneral for External Policies of the Union Directorate B Policy Department Study, European Parliament, April 2012.

Ehrhart H.G., Petretto K., The EU and Somalia: Counter-Piracy and the Question of a Comprehensive Approach, Study for The Greens/European Free Alliance, Hamburg 2012.

Eilstrup-Sangiovanni M., The EU's Common Security and Defence Policy and the Mali Crisis, 16 August 2013, http://www.e-ir.info/2013/08/16/ the-eus-common-security-and-defense-policy-and-the-mali-crisis (access 25.11.2021). 
Fiott D., Introduction, in: The CSDP in 2020. The EU's legacy and ambition in security and defence, ed. D. Fiott, European Union Institute for Security Studies (EUISS), Paris 2020.

Fitzgerad M., Somalia's future relies on an army that does not yet exist, "The Irish Times", Nov 4, 2013, https://www.irishtimes.com/news/world/ africa/somalia-s-future-relies-on-an-army-that-does-not-yet-exist1.1582453 (access 25.11.2021).

France's reset in Africa, "The Economist" 05-11 June 2021.

Frankowski P., Słomczyńska I., Unia Europejska - Afryka Subsaharyjska. Uwarunkowania. Mechanizmy. Efektywność wspótpracy, Wydawnictwo UMCS, Lublin 2011.

Gebhard C., Smith S.J., The two faces of EU-NATO cooperation: Counterpiracy operations off the Somali coast, "Cooperation and Conflict", vol. 50(1)/2015, DOI: https://doi.org/10.1177/0010836714532917.

Gebhard C., Smith S.J., Beyond Rivalry? EU-NATO Cooperation in CounterPiracy Operations, http://piracy-studies.org/2014/beyond-rivalry-eunato-cooperation-in-counter-piracy-operation/ (access 28.11.2021).

Gegout C., Causes and Consequences of the EU's Military Intervention in the Democratic Republic of Congo: A Realist Explanation, "European Foreign Affairs Review", vol. 10(3)/2005.

Górka-Winter B., Misja Unii Europejskiej w Demokratycznej Republice Konga (EUFOR RD Congo), "Biuletyn PISM", no. 384/2006.

Gowan R., Bordering on Crisis: Europe, Africa, and a New Approach to Crisis Management, "Policy Brief", April 2017, European Council on Foreign Relations.

Helly D., EU NAVFOR Somalia, in: ESDP: The first 10 years (1999-2009), eds. G. Grevi, D. Helly, D. Keohan, EU Institute for Security Studies, Paris 2009.

Howorth J., Security and Defence Policy in the European Union, Springer, Basingstoke 2007, https://doi.org/10.1007/978-1-137-04439-6.

https://eeas.europa.eu/topics/military-and-civilian-missions-andoperations/430/military-and-civilian-missions-and-operations_en (access 28.11.2021).

János T., Operation "Artemis": The First Autonomous EU-led Operation, "AARMS", vol. 14(1)/2015, DOI: https://doi.org/10.32565/ aarms.2015.1.11.

Lavallée Ch., Völkel J.C., EU security governance in the Sahel region: Implementing a multidimensional strategy in an unstable environment, Paper, presented at the IPSA Annual Conference Montreal, 21 July 2014.

Lindstrom G., Emerging security challenges. Four futures for CSDP, in: The CSDP in 2020. The EU's legacy and ambition in security and defence, 
European Union, ed. D. Fiott, Institute for Security Studies (EUISS), Paris 2020.

Major C., EUFOR RD Congo, in: ESDP: The first 10 years (1999-2009), eds. G. Grevi, D. Helly, D. Keohan, EU Institute for Security Studies, Paris 2009.

Manners I., Normative power Europe reconsidered: beyond the crossroads, "Journal of European Public Policy", vol. 13(2)/2006, DOI: https://doi. org/10.1080/13501760500451600.

Meijnders M., Zandee D., The CSDP in Africa, in: The EU as a security actor in Africa. In-depth study Clingendael Monitor 2016, ed. D. Zandee, Netherlands Institute of International Relations "Clingendael", The Hague 2015, https://www.clingendael.org/sites/default/files/2016-02/ EU_as_a_security_actor_in\%20Africa_In-depth_study_Clingendael Monitor_2016.pdf (access 10.11.2021).

Menon A., Empowering paradise? The ESDP at ten, "International Affairs", vol. 85(2)/2009, DOI: https://doi.org/10.1111/j.1468-2346. 2009.00791.x.

Miller B., Democracy Promotion: Offensive Liberalism versus the Rest (of IR Theory), "Millennium: Journal of International Studies", vol. 38(3)/2010, DOI: https://doi.org/10.1177/0305829810366475.

Norheim-Martinsen P.M., The EU in Africa: peacebuilding by proxy, Noref Report - October 2013, https://www.files.ethz.ch/isn/172333/f486d101 d4f46690d710109f9f466c73.pdf (access 10.11.2021).

Nováky N.I.M.,From EUFOR to EUMAM: The European Union in the Central African Republic, "European Foreign Affairs Review", vol. 21(1)/2016.

Olsen G.R., The EU and Military Conflict Management in Africa: For the Good of Africa or Europe?, "International Peacekeeping", vol. 16(2)/2009.

Palm T., Crum B., Military operations and the EU's identity as an international security actor, "European Security", vol. 28(4)/2019, DOI: https://doi.or $\mathrm{g} / 10.1080 / 09662839.2019 .1667769$.

Pohl B., The Logic Underpinning EU Crisis Management Operations, "European Security", vol. 22(3)/2013, DOI: https://doi.org/10.1080/0 9662839.2012.726220.

Raubo J., Operacja wojskowa EUTM SOMALIA, in: Operacje wojskowe Unii Europejskiej w Afryce, ed. B. Przybylska-Maszner, Poznań 2014.

Rękawek K., Terlikowski M., EU CSDP in the Light of the Crisis in Mali, "PISM Bulletin", no. 21(997)/2013.

Shurkin M., Pezard S., Zimmerman S.R., Mali's Next Battle. Improving Counterterrorism Capabilities, RAND Corporation, London 2017, https://www.rand.org/content/dam/rand/pubs/research_reports/ RR1200/RR1241/RAND_RR1241.pdf (access 25.11.2021). 
Sixdenier B., Stability spectrum: the battle for stabilization in the Central African Republic, "IRSEM Research Paper", no. 42/2017.

Somalia SSR Background Note, http://issat.dcaf.ch/Learn/ResourceLibrary/Country-Profiles/Somalia-SSR-Background-Note (access 26.11.2021).

Stavridis S., Why the 'Militarising' of the European Union is Strengthening the Concept of a Civilian Power Europe, "EUI Working Papers", no. 1/2001, DOI: https://doi.org/10.1080/03932720108456945.

Tardy T., EUFOR RCA: tough start, smooth end, "Issue Alert", March 2015, European Union Institute for Security Studies.

The EU and the world: players and policies post-Lisbon, ed. A. Missiroli, A handbook, EU Institute for Security Studies, Paris 2016.

United Nations, Department of Economic and Social Affairs, Population Division, The World's Cities in 2018-Data Booklet (ST/ESA/ SER.A/417), 2018, https://www.un.org/en/events/citiesday/assets/pdf/ the_worlds_cities_in_2018_data_booklet.pdf (access 26.11.2021).

United Nations. Economic Commission for Africa, Policy brief: impact of COVID-19 in Africa, Addis Ababa, 20 May 2020.

Walker T.C., Two Faces of Liberalism: Kant, Paine, and the Question of Intervention, "International Studies Quarterly", no. 52/2008, DOI: https://doi.org/10.1111/j.1468-2478.2008.00510.x.

Zajączkowski K., CSDP missions and operations as instruments of $E U$ crisis management - their essence, role and determinants, "On-line Journal Modelling the New Europe”, no. 34/2020, DOI: https://doi. org/10.24193/OJMNE.2020.34.01.

Zajączkowski K., Misje cywilne $i$ operacje wojskowe Unii Europejskiej w perspektywie wybranych teorii stosunków międzynarodowych $i$ integracji europejskiej, Centrum Europejskie UW, Warsaw 2019. 